Gut, 1960, 1, 146.

\title{
EFFECT OF GLUCAGON ON GASTRIC SECRETION IN THE DOG*
}

\author{
BY \\ S. D. ClARKE, D. W. NEILL, and R. B. WELBOURN \\ From the Department of Surgery, the Queen's University, Belfast, and the Biochemistry Laboratory, \\ Royal Victoria Hospital, Belfast
}

The effects of glucagon on gastric secretion in the dog have been studied. Gastric juice was collected both from denervated and innervated pouches under basal conditions and when the animals were stimulated by meat extract and by histamine. In the dogs with innervated pouches psychic stimulation and the stimulatory action of insulin-induced hypoglycaemia were also used.

Glucagon reduced the volume but not the acidity of gastric juice collected under all conditions. This effect was independent of its hyperglycaemic action and occurred when physiological doses were administered.

Soon after the discovery of insulin it was noted that certain extracts of the pancreas induced a rise, instead of the usual fall, in the blood sugar level. This activity was attributed to a hypothetical hyperglycaemic factor, to which the name "glucagon" was given (Murlin, Clough, Gibbs, and Stokes, 1923). Glucagon has now been isolated and analysed and it is probable, though not certain, that it is formed in the alpha cells of the Islets of Langerhans.

In the Zollinger-Ellison syndrome a tumour of the islet cells is associated with gross gastric hypersecretion and with fulminating peptic ulceration. While most of these tumours do not secrete insulin, it is possible that they secrete a humoral agent which stimulates the production of acid and thus causes the ulcers. The tumours are usually composed of alpha cells (Gibson and Welbourn, 1960), and it has been suggested that they secrete glucagon and that this is the cause of the hyperacidity (Zollinger and Ellison, 1955; Lancet, 1959). This suggestion led several workers to investigate the effects of glucagon on gastric function.

It had been noted already that the intravenous administration of insulin caused a decrease in gastric secretion before the usual hypersecretory response (Olson and Necheles, 1953). It seems possible, in the light of later work, that this was the result of contamination of the insulin by glucagon. Glucagon reduces the volume and the acidity of the basal secretion in man (Robinson, Harris, Hlad, and

* Presented at the Annual Meeting of the British Society of Gastroenterology at Belfast on Nov. 6, 1959.
Eiseman, 1957; Dall and Melrose, 1959; Dreiling and Janowitz, 1959) and it abolishes the acid secretory response to a meal and to insulin in the $\operatorname{dog}$ (Lin and Alphin, 1958). The response to histamine is reduced by glucagon in man (Cohen, Mazure, Dreiling, and Janowitz, 1959) but not in the dog (Lin and Alphin, 1958). Glucagon reduces the secretion of pepsin in the gastric juice in man (Cohen et al., 1959; Dreiling and Janowitz, 1959) and lowers the concentration of pepsinogen in the blood in man and in the dog (Earle, Cahill, and Hoar, 1957). It also reduces gastric motility (Stunkard, Van Itallie, and Reis, 1955; Robinson et al., 1957).

It has been suggested that the inhibitory effect is secondary to the concomitant hyperglycaemia. Some (Earle et al., 1957) observed a similar depression of gastric secretion when they injected glucose intravenously, but others (Stunkard et al., 1955; Robinson et al., 1957) found that the period of inhibition corresponded to that when the difference between the concentration of glucose in the arterial or capillary blood and that in the venous blood was greatest. Others (Cohen et al., 1959) failed to correlate the inhibition with the blood glucose level.

This investigation was undertaken to determine:

(1) The effects of glucagon on the volume and acidity of gastric juice in the dog under different conditions; (2) the relation of gastric secretion to the blood glucose level; (3) the doses of glucagon which would influence the stomach and the blood glucose level respectively. 


\section{MATERIALS AND METHODS}

Six smooth-haired mongrel bitches, weighing $7 \cdot 8$ to $11.9 \mathrm{~kg}$., were used. Denervated (Heidenhain) pouches were prepared in four and innervated (Pavlov) pouches (Gregory, Hallenbeck, and Code, 1942) in two. They were fitted with "duralumin" cannulae. The animals were not tested for at least five weeks after operation. They were fed on a standard diet of meat offal and pig starter meal in equal parts. Each dog was fed once daily with a measured quantity sufficient to provide approximately 70 calories per $\mathrm{kg}$. per day. They were fasted for 18 hours before each test.

Gastric juice was collected in graduated tubes. The volume was read off directly and the $p \mathrm{H}$ was measured on a direct-reading $p \mathrm{H}$ meter. Except when stated otherwise, the juice was collected for half an hour. Collections were made under the following conditions.

\section{Both Types OF Pouch}

(1) Basal Secretion.-In these tests the gastric juice was collected for four hours from the unstimulated pouch.

(2) Antral Stimulation.-The gastric antrum was stimulated by the injection of meat extract $(35 \mathrm{ml}$. of a $20 \%$ solution of "bovril" at $p \mathrm{H} \mathrm{5.4)}$ into the stomach through a polythene tube.

\section{Denervated Pouches OnLy}

(3) Histamine Stimulation.-Histamine acid phosphate (B.P.) was injected subcutaneously in a dose of $1 \mathrm{mg}$. histamine base per $10 \mathrm{~kg}$. body weight. Half an hour before the administration of histamine $5 \mathrm{mg}$. of chlorpheniramine maleate (an antihistaminic drug) was given subcutaneously. Collections were started after the injection of histamine.

\section{INNERVATED POUCHES}

(4) Psychic Stimulation.-Three types of stimuli were combined.

Sight.-The meal was placed within sight, but out of reach, of the dog.

Smell.-A solution of meat extract was boiled in the room.

Taste.-One lick of a spoon lightly smeared with meat extract.

The technician who usually fed the dogs was present in the room during the tests.

(5) Hypoglycaemic Stimulation.-Soluble insulin was given intravenously in doses of 20 or 40 units. Glucose ( $40 \mathrm{ml}$. of $50 \%$ solution) was given orally after the tests to prevent severe hypoglycaemic reactions.

\section{Dosage of Glucagon}

Crystalline glucagon in an aqueous solution was injected intravenously. The dose was $1.0 \mathrm{mg}$. except where stated otherwise. Its injection did not cause any rise in the rectal temperature. Varying doses of glucose, in a $50 \%$ aqueous solution, were injected intravenously.

Blood glucose estimations were made by a micromodification of the method of Folin and Wu (1920), suitably altered to yield "true glucose" values.

\section{RESULTS}

\section{EfFect of Glucagon on Secretion from Denervated Pouches}

Glucagon reduced the volume of the secretion under basal conditions and when stimulated by meat extract. It did not influence the histaminestimulated secretion significantly (Table I). There was no consistent effect on the acidity.

TABLE I

EFFECT OF GLUCAGON ON GASTRIC SECRETION FROM DENERVATED POUCHES*

\begin{tabular}{|c|c|c|c|}
\hline & Control & Glucagon & $\begin{array}{c}\text { Mean \% } \\
\text { Differencet }\end{array}$ \\
\hline $\begin{array}{l}\text { Volume (ml./ } \frac{1}{2} \text { hour) } \\
\text { Unstimulated } \\
\text { Increase with:* } \\
\text { Meat extract } \\
\text { Histamine }\end{array}$ & $\begin{array}{c}0.63 \mp(27) \\
3.61(22) \\
10.24(22)\end{array}$ & $\begin{array}{l}0.32(8) \\
0.42(7) \\
8.94(8)\end{array}$ & $\begin{array}{l}-52 \cdot 5 \\
-78 \cdot 8 \\
-12 \cdot 0\end{array}$ \\
\hline $\begin{array}{l}p \mathbf{H}_{\text {Unstimulated }} \\
\text { Meat extract } \\
\text { Histamine }\end{array}$ & $\begin{array}{l}5 \cdot 5(27) \\
1.7(22) \\
1 \cdot 3(22)\end{array}$ & $\begin{array}{l}4.8(8) \\
2.5(7) \\
1.4(8)\end{array}$ & $\begin{array}{l}-13 \\
+38 \\
+4\end{array}$ \\
\hline
\end{tabular}

*Stimulated minus unstimulated volume.

tGlucagon minus control values.

$\ddagger$ All figures are the averages of the means for the 4 dogs.

Number of tests shown in brackets.

\section{EfFect of Glucagon on SeCretion from INNERVATED POUCHES}

Glucagon did not affect the volume of the basal secretion (which was very low). It abolished the secretory response to psychic stimuli and reduced appreciably the responses to hypoglycaemia and to meat extract. Insulin (20 units) overcame the hyperglycaemic effect of the glucagon and produced blood sugar levels of 26 to $31 \mathrm{mg}$. per $100 \mathrm{ml}$. There was no consistent effect on the acidity.

TABLE II

EFFECT OF GLUCAGON ON GASTRIC SECRETION FROM INNERVATED POUCHES

\begin{tabular}{|c|c|c|c|}
\hline & Control & Glucagon & $\begin{array}{c}\text { Mean \% } \\
\text { Differencet }\end{array}$ \\
\hline $\begin{array}{l}\text { Volume (ml./1 hour) } \\
\text { Unstimulated } \\
\text { Increase with:* } \\
\text { Psychic stimulation } \\
\text { Insulin } \\
\text { Meat extract }\end{array}$ & $\begin{array}{l}0.5 \ddagger(11) \\
2.25(11) \\
3.9(8) \\
6.7(7)\end{array}$ & $\begin{array}{l}0.5(5) \\
0.0(6) \\
1.4(6) \\
1.8(6)\end{array}$ & $\begin{array}{r}0 \\
-100 \\
-\quad 65 \\
-\quad 69\end{array}$ \\
\hline $\begin{array}{l}p \mathbf{H}_{\text {Unstimulated }} \\
\text { Psychic stimulaticn } \\
\text { Insulin } \\
\text { Meat extract }\end{array}$ & $\begin{array}{l}5.9(11) \\
2.0(8) \\
2.9(7)\end{array}$ & $\begin{array}{c}6.0(5) \\
2.0(6) \\
3 \cdot 1(6)\end{array}$ & $\begin{array}{r}+3 \\
0 \\
+15\end{array}$ \\
\hline
\end{tabular}

*Stimulated minus unstimulated volume.

†Glucagon minus control values.

All figures are the averages of the means for the 2 dogs.

Number of tests shown in brackets.

Effects of Glucose and Glucagon Plus Insulin on Secretion from Denervated Pouches

Glucose, given intravenously in doses between 2.7 and $15.0 \mathrm{~g}$., produced blood sugar curves similar 
to those which followed glucagon $(1.0 \mathrm{mg}$.) (Table III). It did not, however, reduce the volume or the acidity of the unstimulated secretion or that

TABLE III

EFFECT OF GLUCAGON (1.0 mg.) AND OF GLUCOSE $(10 \mathrm{~g}$. ON BLOOD SUGAR IN A TYPICAL EXPERIMENT

\begin{tabular}{c|c|c|c|c|c}
\hline Time (min.) & 0 & 15 & 30 & 45 & 60 \\
\hline $\begin{array}{c}\text { Blood glucose (mg./100 ml.) } \\
\begin{array}{c}\text { Glucagon } \\
\text { Glucose }\end{array}\end{array}$ & 68 & 125 & 104 & 89 & 64 \\
\hline
\end{tabular}

This effect of glucagon on the stomach is probably a direct one and not a result of hyperglycaemia. Glucose, which raised the blood sugar level to the same extent as glucagon, did not influence the secretion, and glucagon still greatly reduced the response to meat extract when hyperglycaemia was prevented by insulin.

The fact that glucagon affects the stomach in doses similar to those which raise the blood sugar suggests that it may play a part in the physiological

TABLE IV

EFFECT OF GLUCOSE ON GASTRIC SECRETION FROM DENERVATED POUCHES

\begin{tabular}{|c|c|c|c|c|c|c|}
\hline & \multicolumn{3}{|c|}{ Control } & \multicolumn{3}{|c|}{ Glucose } \\
\hline & No. of Tests & Volume (ml./ $\left.\frac{1}{2} \mathrm{hr}.\right)$ & $p H$ & No. of Tests & $\overline{\text { Volume (ml./1/2hr.) }}$ & $p H$ \\
\hline $\begin{array}{l}\text { Unstimulated } \\
\text { Stimulated with: }\end{array}$ & 5 & $0.6^{*}$ & $5 \cdot 8$ & 2 & 0.5 & $3 \cdot 2$ \\
\hline $\begin{array}{l}\text { Meat extract } \\
\text { Histamine }\end{array}$ & $\begin{array}{l}5 \\
5\end{array}$ & $\begin{array}{l}3 \cdot 3 \\
7 \cdot 9\end{array}$ & $\begin{array}{l}1 \cdot 7 \\
1 \cdot 2\end{array}$ & $\begin{array}{l}4 \\
1\end{array}$ & $\begin{array}{l}5 \cdot 4 \\
9 \cdot 0\end{array}$ & $\begin{array}{l}1 \cdot 2 \\
1 \cdot 2\end{array}$ \\
\hline
\end{tabular}

*All figures are mean values. The small differences are not statistically significant.

TABLE V

EFFECT OF GLUCAGON AND INSULIN TOGETHER ON MEAT-EXTRACT-STIMULATED SECRETION FROM DENERVATED POUCHES

\begin{tabular}{|c|c|c|c|c|c|c|}
\hline & \multicolumn{3}{|c|}{ Dog 201} & \multicolumn{3}{|c|}{$\operatorname{Dog} 202$} \\
\hline & No. of Tests & Volume (ml. $\left./ \frac{1}{2} \mathrm{hr}.\right)$ & $p H$ & No. of Tests & Volume (ml./ $\left.\frac{1}{2} \mathrm{hr}.\right)$ & $p \mathbf{H}$ \\
\hline $\begin{array}{l}\text { Control } \\
\text { Glucagon and insulin }\end{array}$ & $\begin{array}{l}5 \\
4\end{array}$ & $\begin{array}{l}3 \cdot 0^{*} \\
1 \cdot 2\end{array}$ & $\begin{array}{l}1 \cdot 7 \\
2 \cdot 2\end{array}$ & $\begin{array}{l}5 \\
1\end{array}$ & $\begin{array}{l}1 \cdot 3 \\
0.6\end{array}$ & $\begin{array}{r}2 \cdot 0 \\
3 \cdot 3\end{array}$ \\
\hline
\end{tabular}

*All figures are mean values.

induced by meat extract or histamine (Table IV). In a further experiment, in which meat extract was used as the gastric stimulant, insulin (40 units) was given 15 minutes before the glucagon to prevent a rise in the blood sugar. Secretion was still inhibited (Table V).

EfFects of Varying Doses of Glucagon on Blood Sugar and on Gastric Secretion

Secretion in response to meat extract was greatly reduced by glucagon in a dose of $0.1 \mathrm{mg}$. (one tenth of that used in 1-3 above), but was not affected when the dose was reduced to $0.05 \mathrm{mg}$. or $0.01 \mathrm{mg}$. A significant rise in the blood sugar $(8 \mathrm{mg}$. per $100 \mathrm{ml}$.) was produced by doses of $0.05 \mathrm{mg}$. and more, but not by $0.01 \mathrm{mg}$.

\section{DISCUSSION}

Glucagon reduces the volume of gastric secretion under basal conditions and after all the forms of stimulation which were used. (The volume of the unstimulated juice from the innervated pouches was too low for any differences to be detected.) It does not, apparently, affect the acidity, indicating that the composition of the juice (in this respect) is unchanged. It is, therefore, very unlikely that glucagon is the cause of gastric hypersecretion in the ZollingerEllison syndrome. regulation of gastric secretion. Glucagon is probably secreted maximally during the fasting state to prevent hypoglycaemia. It would certainly perform a useful function if, at the same time, it tended to prevent the secretion of gastric juice by the empty stomach.

We wish to thank the following for their help: Mr. H. O. Nevin, Mr. J. Tansey, and Mr. J. Mullan for technical assistance; the technical staff of the Biochemical Laboratory, Royal Victoria Hospital, Belfast; Miss B. H. S. Foster and Miss H. N. Pountain for the secretarial work; Messrs. Eli Lilly and Co. and, in particular, Dr. P. L. Kurtz, for the generous gift of all the glucagon used in this study.

\section{REFERENCES}

Cohen, N., Mazure, P., Dreiling, D. A., and Janowitz, H. D. (1959). Fed. Proc., 18, 28.

Dall, J. H. C., and Melrose, A. G. (1959). Lancet, 1, 258.

Dreiling, D. A., and Janowitz, H. D. (1959). Gastroenterology, 36,580

Earle, A. S., Cahill, G. F., and Hoar, C. S. (1957). Ann. Surg., Folin, O., and Wu, H. (1920). J. biol. Chem., 41, 367.

Gibson, J. B., and Welbourn, R. B. (1960). Postgrad. med. J., 36, 154 .

Gregory, R. A., Hallenbeck, G. A., and Code, C. F. (1942). Proc. Soc. exp. Biol. (N.Y.), 49, 400.

Lancet (1959), 1, 133 [Leading article.]

Lin, T. M., and Alphin, R. S. (1958). Fed. Proc., 17, 97.

Murlin, J. R., Clough, H. D., Gibbs, C. B. F., and Stokes, A. M. (1923).' J. biol. Chem., 56, 253.

Olson, W. H., and Necheles, H. (1953). Gastroenterology, 24, 362. Robinson, R. M., Harris, K., Hlad, C. J., and Eiseman, B. (1957). Proc. Soc. exp. Biol. (N.Y.), 96, 518 .

Stunkard, A. J., Van Itallie, T. B., and Reis, B. B. (1955). Ibid.

Zollinger, R. M., and Ellison, E. H. (1955). Ann. Surg., 142, 709. 